\title{
THE UNCERTAIN LINK BETWEEN GALLSTONE DISEASE AND COLORECTAL CANCER
}

\author{
Ahmed Mohssen, Andreea Alexandra Nicola, Denisa Predețeanu, Narcis Copcă \\ "Sf. Maria" Clinical Hospital, Bucharest, Romania \\ Corresponding author: Ahmed Mohssen \\ E-mail: dr.ahmedansari1@gmail.com
}

\begin{abstract}
Colorectal cancer (CRC) is one of the most commonly diagnosed cancers worldwide and is a major cause of cancer-related mortality. While environmental and genetic factors have a major and well-known contribution in its pathogenesis, research has suggested that nutrition and lifestyle may also play a central role in the development of this neoplasm. Moreover, metabolic, hormonal and biochemical changes in the digestive tract can create a favorable ground for tumor development in the colonic epithelium.

Gallstone disease are a very common gastrointestinal disease that often remains asymptomatic, without being a major health problem. However, epidemiological studies have shown a link between the occurrence of right-sided colon cancers and the presence of gallstones which led to an increasing interest in the mechanisms that may underlie this association. Although the two pathologies share numerous risk factors (obesity, metabolic syndrome, hypercholesterolemia, diabetes, high-fat diet, sedentary lifestyle, old age), gallstones may be at the intersection of several CRC pathways. Whether it's metabolic changes in bile acids and cholesterol, changes of the gut microbiota, or even inflammation, gallstones could independently promote the appearance of colorectal tumors.

In this review article, we aim to provide an assessment of the factors and mechanisms by which gallstones and cholecystectomy could influence the development of CRC. It is also important to consider whether the profile of the gallstone patient could be included in individualized screening programs for the early detection of CRC.
\end{abstract}

Keywords: gallstone disease, cholecystectomy, colorectal cancer, risk factors.

\begin{abstract}
Cancerul colorectal (CRC) este una dintre cele mai frecvent diagnosticate neoplazii la nivel mondial și reprezintă o cauză majoră de mortalitate prin cancer. În timp ce factorii de mediu și genetici au o contribuție majoră și bine cunoscută în patogeneza sa, cercetările sugerează că nutriția și stilul de viață pot juca, de asemenea, un rol central în dezvoltarea acestui neoplasm. Mai mult, modificările metabolice, hormonale și biochimice ale tractului digestiv pot crea un teren favorabil dezvoltării tumorii în epiteliul colonic.
\end{abstract}




\section{INTERNAL}

\section{General Reviews}

Litiaza biliară este o afecțiune gastro-intestinală foarte frecventă care rămâne adesea asimptomatică, fără a reprezenta o problemă majoră de sănătate. Cu toate acestea, studiile epidemiologice au arătat o legătură între apariția cancerului de colon drept și prezența calculilor biliari, ceea ce a dus la un interes în creștere pentru mecanismele care pot sta la baza acestei asocieri. Deși cele două patologii împărtășesc numeroși factori de risc (obezitate, sindrom metabolic, hipercolesterolemie, diabet, dietă bogată în grăsimi, stil de viață sedentar, vârstă înaintată), calculii biliari pot apărea la intersecția mai multor căi împlicate în CRC. Calculii biliari pot promova în mod independent apariția tumorilor colorectale, fie prin modificări metabolice ale acizilor biliari și colesterolului, fie prin modificări ale microbiotei intestinale sau chiar prin prezența inflamației.

în acest articol ne propunem o evaluare a factorilor și mecanismelor prin care prezența calculilor biliari și colecistectomia ar putea influența dezvoltarea CRC. De asemenea, este important să se ia în considerare dacă pacientul cu calculi biliari ar putea fi inclus în programele de screening individualizate pentru detectarea precoce a CRC.

Cuvinte cheie: litiază biliară, colecistectomie, cancer colorectal, factori de risc.

\section{Introduction}

Colorectal cancer (CRC) is one of the most common types of cancer in the world. Between 1 and 2 million new cases are diagnosed annually, ranking 3rd in the top of the most common types of cancer and 4 th as the cause of deaths due to cancer ${ }^{(1)}$. Research in the field of CRC has advanced considerably in the last decades, due to the everincreasing incidence of this pathology globally. Despite the public health problem of colorectal cancer worldwide, mortality has dropped significantly, mainly due to innovations in screening and therapy. The importance of screening is crucial as long as the signs and symptoms are few and nonspecific in the early stages and it contributes substantially to the prevention of high morbidity, mortality and expensive treatment. Thus, significant lesions are detected before they become cancerous or the existence of early stages of CRC is established before it spreads in the body. Colonoscopy is currently the standard for colorectal cancer screening and is recommended to be performed periodically in people over the age of 50 . At the same 
time, during colonoscopy, therapeutic maneuvers such as polypectomy can be performed, which improves long-term survival ${ }^{(1-3)}$.

Although anyone can develop colorectal cancer, there are many risk factors associated with this condition. Among them, certain factors are modifiable: diet, obesity, lack of physical activity, smoking and alcohol consumption, but others are unchangeable: age, ethnicity, family history of colorectal cancer and colon polyps, hereditary diseases, the presence of type I or type II diabetes and so on ${ }^{(4)}$. Numerous studies have explored over time the link between the presence of gallstones and the possibility of developing $\mathrm{CRC}^{(5-9)}$. The association between gallstones and CRC can be determined by alterations of the intestinal microbiota, changes in bile metabolism, as well as the cellular and molecular effect on the intestinal mucosa. Evidence to date has suggested that exposure of gastrointestinal epithelial cells to high levels of secondary bile acids may increase the predisposition to gastrointestinal cancers. On the other hand, other conditions may also contribute to the development of a colorectal tumor in patients suffering from gallstones. An example of common risk factor is obesity, which is a definite metabolic substrate for both gallstones and CRC.

Considering gallstones as a risk factor for $\mathrm{CRC}$, as well as the many common risk factors for both diseases, it is important to determine whether patients with long-known biliary disorders could benefit from a complete analysis of their health and of a detailed assessment of the digestive tract. Regarding surgeries, the number of minimally invasive procedures has increased, currently laparoscopic cholecystectomy being preferred over laparotomy ${ }^{(10)}$. In this way, the surgical exploration of the digestive tract is less complete, decreasing the rate of incidental detection of tumors at this level. Preoperative colonoscopy in this group of patients and especially in those to undergo laparoscopic surgery, could be essential in the early detection and treatment of colorectal malignancies.

\section{Bile acids and their role in carcinoge-nesis}

The existence of a possible carcinogenic effect of bile acids has been considered since 1940. The first studies investigated the formation of tumors in mice under the action of deoxycholic acid ${ }^{(1)}$. Based on this idea, further research has examined the mechanisms by which bile acids could be a risk factor for gastrointestinal and CRC.

Primary bile acids (cholic acid and chenodeoxycholic acid) are derived from cholesterol and are synthesized in the liver. From the liver, they are excreted and stored in the gallbladder as conjugated amides with glycine or taurine and then released in the intestinal tract ${ }^{(22)}$.

Once in the intestinal tract, they facilitate the absorption of lipids, cholesterol and fatsoluble vitamins. Basically, they act as a physiological detergents, while maintaining the homeostasis of the intestinal epithelium ${ }^{(13.4)}$. About $95 \%$ of bile acids are rapidly reabsorbed in the terminal ileum and return to the liver via the portal circulation, leaving less than $5 \%$ to reach the colon.

The primary bile acids that reach the large intestine are metabolized by the anaerobic bacterial flora through a series of enzymatic reactions. The first is the deconjugation reaction to release free bile acids, which are only slightly ionized and are lipophilic. The second major reaction is $7 \alpha$-dehydroxylation which leads to the transformation of primary bile acids into secondary bile acids: 


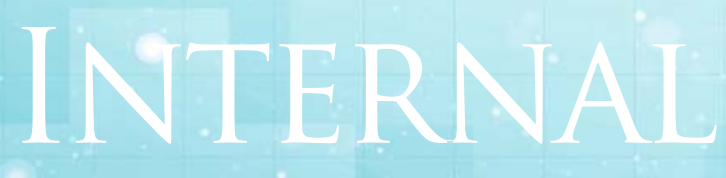

General Reviews

deoxycholic acid (from colic acid) and lithocholic acid (from chenodeoxycholic acid $)^{(14,15)}$. Deoxycholic acid is partially absorbed in the colon and enters the enterohepatic circulation, where it is conjugated in the liver and secreted into the bile. On the other hand, lithocholic acid is quite insoluble and is slightly reabsorbed. Other biochemical reactions of bile acids in the colon (oxidation of hydroxyl groups, epimerization and dehydrogenation of the sterol nucleus), lead to the formation of tertiary bile acids, such as ursodeoxycholic acid, and to other compounds that enter the digestive tract.

Thus, the bile acid composition of the intestinal content differs significantly along the digestive tract and is made up of $30-40 \%$ each of cholic acid and chenodeoxycholic acid, about $20-30 \%$ of deoxycholic acid, and less than $5 \%$ of lithocholic acid (Figure 1$)^{14,16,}$ ${ }^{17)}$. It is well known that the "Western" diet is strongly associated with the increased incidence of colorectal cancer. Eating habits have the ability to influence the development of CRC both directly through specific elements that foods contain and indirectly through numerous metabolic changes or by affecting the intestinal microbiota ${ }^{(8,19)}$.

Moreover, the diet significantly modifies the synthesis and secretion of bile acids. Increased fat intake is associated with elevated levels of secondary bile acids in the digestive tract. Population studies have shown that subjects who consume foods high in fat and beef have a high level of fecal secondary biliary acids, mostly deoxycholic and lithocholic acids, as well as patients diagnosed with colon cancer. These increased levels of bile acid concentration have an effect not only on the structure of the colonic epithelium, but also on its function ${ }^{06}$. $17,20)$

To date, studies have not fully elucidated the mechanisms by which secondary bile acids (deoxycholic and lithocholic acid) influence the tumor transformation of intestinal epithelial cells, but there are several hypotheses regarding this. First of all, the cocarcinogenic and co-mutagenic effect of secondary bile acids was demonstrated in vitro.

Their chemical structure was considered to play a key role in this process. The number of hydroxyl groups was considered to be inversely proportional to genotoxicity. Thus, lithocholic acid, being monohydroxylated, seems to have the highest genotoxicity. Regarding deoxycholic acid, a dihydroxylated acid, the increased genotoxicity is given by the position of the second hydroxyl group (Figure 2) (21). $^{2}$.

In vivo, the action of secondary bile acids on the colonic mucosa is complex and multiple biochemical and genetic pathways have been studied to alter the structure of the intestinal 


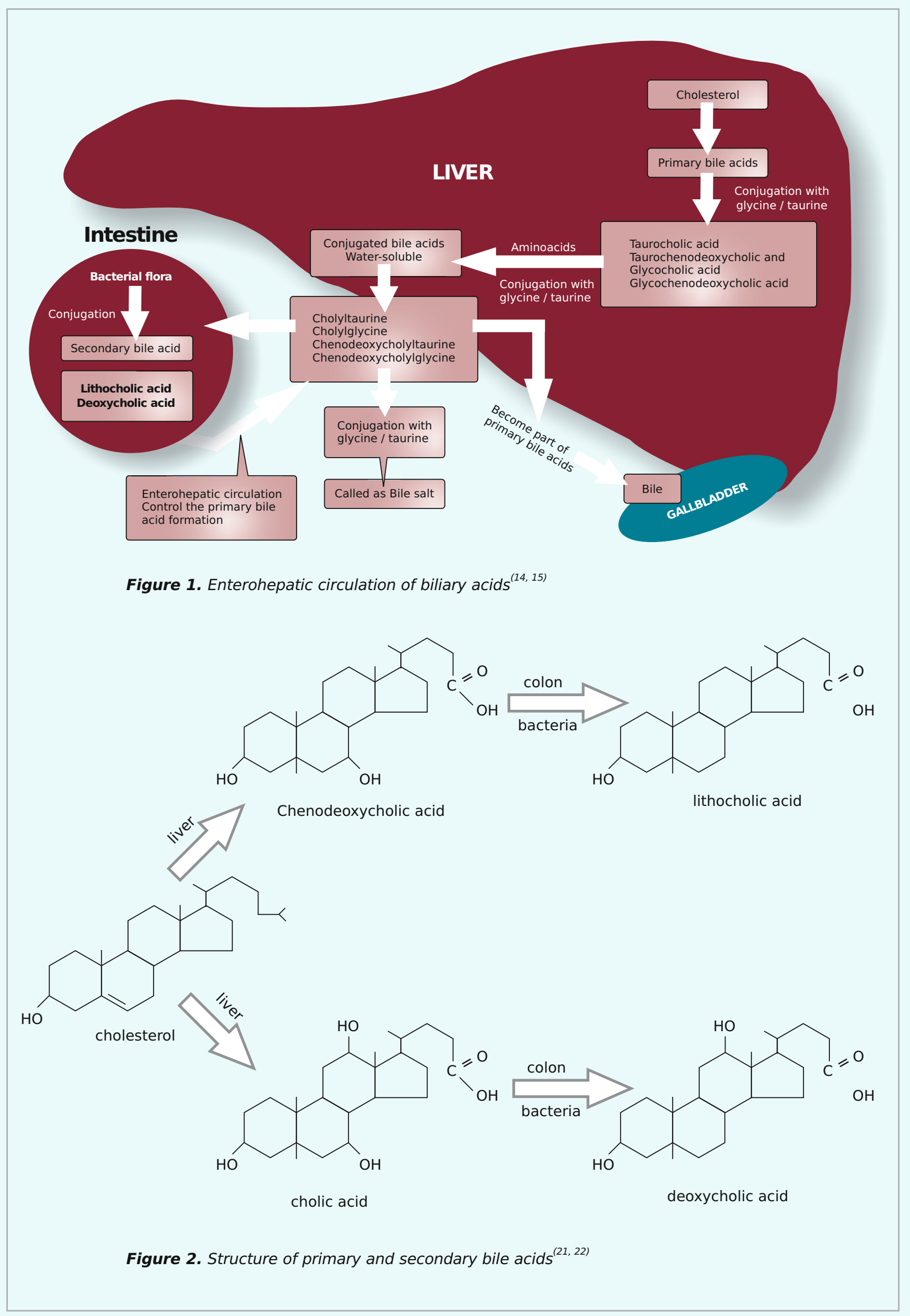






General Reviews

epithelium. Having hydrophobic properties, they act as a detergent on lipids, leading to an altered lipid bilayer of plasmatic membrane and increased paracellular permeability in a dose-related manner ${ }^{23)}$.

Subsequent repair mechanisms involving inflammatory reactions and undifferentiated cell hyperproliferation would then increase the risk of transition to a precancerous state $^{24)}$. High concentrations of secondary bile acids can also induce colonic epithelial cell proliferation by activating epidermal growth factor receptors (EGFRs) ${ }^{25)}$.

Furthermore, secondary bile acids can activate protein kinase C (PKC) (an enzyme involved in cell growth control and tumor promotion), through multiple mechanisms. One of these mechanisms is the generation of diacylglycerol, a physiological activator of the enzyme. Diacylglycerol is produced by the intestinal flora under the influence of diet and bile acids, especially deoxycholic acid. At the same time, PKC can be activated downstream of EGFR or by membrane disturbances ${ }^{(26,27)}$.

One of the most important cytotoxic effects of bile acids is the production of reactive oxygen and nitrogen species by several different pathways involving cell membrane alteration and mitochondria. Increased ROS / RNS production can lead to DNA damage and an increased number of mutations ${ }^{24,28)}$. They can also cause changes in cellular apoptosis and can modulate numerous genes / proteins associated with maintaining chromosomal stability and mitosis. All of this damage can lead to genomic instability, which can then result in colon carcinogenesis ${ }^{24,29)}$.

\section{Gallstone disease and colorectal cancer}

Gallstones are one of the most common gastrointestinal disorders. It represents a major health problem in developed societies, affecting about $10-15 \%$ of the adult population $^{(30,31)}$.

The disorder is characterized by the presence in the gallbladder, bile ducts or in both of stones or smaller concretions that make up the so-called "biliary sand". Gallbladder stones are crystalline structures formed by sedimentation of normal or abnormal bile constituents and are divided into three categories depending on their chemical composition: cholesterol gallstones, pigment stones and mixed ones.

Cholesterol and mixed stones are usually the most common type and represents about $75 \%$ of the gallstones in Western countries. They contain over $70 \%$ cholesterol monohydrate, mixtures of calcium salts, bile acids and pigments, and also proteins, phospholipids and fatty acids. Pigment stones are made up mostly of calcium bilirubin, containing less than $20 \%$ cholesterol $^{(3233)}$. 
It is well known that cholesterol gallstones are associated with certain risk factors such as obesity, type 2 diabetes, dyslipidemia and hyperinsulinemia ${ }^{(30)}$, which are actually components of the metabolic syndrome. The prevalence of metabolic syndrome is higher than $35 \%$ in the adult population and continues to increase in Western countries or with the westernization of the diet in less developed countries ${ }^{(34)}$.

Considering this aspect, diet plays an important role in the development of cholesterol gallstones and dictates its geographical spread. Additional risk factors for gallstones include old age, family history of gallstones, ethnicity, sedentary lifestyle and smoking, this condition especially affecting women through exposure to higher estrogen levels, through pregnancy, hormone therapy or estrogen-containing hormonal contraception ${ }^{(35)}$.

Regarding CRC, its development can be explained by numerous alterations of metabolic and endocrine mechanisms ${ }^{(36)}$. Thus, the development of CRC is based on numerous risk factors that are also associated with gallstones. Common risk factors include metabolic syndrome, a highfat diet, obesity, diabetes, sedentary lifestyle, smoking and age. Moreover, studies have suggested that there is a common epitope found on the epithelium of the gallbladder and that of the colorectal mucosa ${ }^{\text {B7). }}$.

Considering the common profile of patients, as well as the frequent incidental discovery of digestive tumors during cholecystectomy interventions, the link between the two diseases has raised multiple questions. To date, population studies have been contradictory regarding the association of colorectal cancer and gallstones. However, known patients with asymptomatic gallstones had an increased risk of gastrointestinal cancer, especially in the right colon.

The risk of developing colorectal tumors was higher in female patients and in those who had a longer history of gallstones ${ }^{(6,36,38,39)}$. In addition to common baseline elements, the involvement of gallstones in the development of colorectal tumors can be explained by alterations in bile secretion, intestinal microbiota or metabolic alterations, which can cause cellular effects in the colonic mucosa ${ }^{0,36)}$.

The synthesis and metabolism of bile acids are influenced by the enterohepatic circulation, as well as the formation of gallstones. Disruptions of this cycle due to genetic, metabolic or intestinal flora changes, can lead to cellular disorders of the intestinal epithelium ${ }^{\beta 6)}$.

According to previous studies, patients with gallstones had significantly higher overall concentrations of fecal bile acids compared to controls. Using liquid chromatography and analyzing the profile of bile acids in the stool of gallstones patients, there was a significant increase in secondary bile acids fecal concentration, an increase inlithocholic acid and glycodeoxycholic acid levels, as well as an increase in lithocholic acid / deoxicholic acid ratios ${ }^{40)}$.

Other findings support the observation that the mRNA level of rate-limiting enzyme in biliary acidssynthesis is increased over $400 \%$ ingallstones patients ${ }^{(41)}$. Thus, the altered fecal bile acid content may reflect an abnormal underlying biliary acids metabolism associated with the formation of gallstones, rather than being a result of their presence $^{(41,42)}$.

Gallstones may be asymptomatic or can manifest through acute or chronic symptoms. The symptoms are most often due to stones 


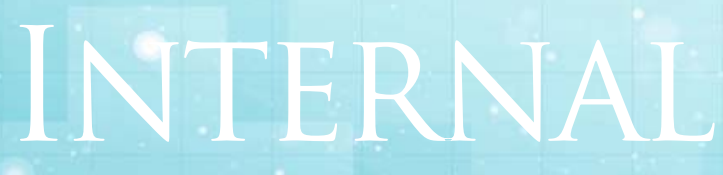

General Reviews

that end up obstructing the bile ducts (especially the cystic duct), causing inflammation of the gallbladder wall and causing acute or chronic cholecystitis. Inflammation in this case can have mechanical substrate by increasing intraluminal pressure and distension followed by ischemia and necrosis of the wall, chemical substrate by releasing local tissue factors, but also bacterial substrate by cantoning a variety of germs at this level ${ }^{(31,43)}$. Gallstones can also lead to many other digestive complications, such as cholangitis, gallbladder pancreatitis, and gallbladder cancer, including inflammation in the tissues adjacent to the gallbladder ${ }^{(44,45)}$. Given that the link between inflammation and cancer is well established $^{46)}$, gallstones could increase the risk of developing digestive tumors through prolonged inflammatory status.

Most commonly, gallstones are accidentally discovered in asymptomatic subjects during routine abdominal ultrasonography, because in most cases (60-80\%) they are asymptomatic ${ }^{(4)}$. Due to low risk of developing cholecystitis, its complications and gallbladder cancer, treatment of patients with asymptomatic gallstones is not recommended. However, management is different in patients with symptomatic gallstones, where surgery, respectively laparoscopic cholecystectomy, is currently the "gold standard" treatment ${ }^{48,49)}$. Although the inflammation caused by gallstones would disappear after cholecystectomy, the bile would reach directly into duodenum, and its secretion would not be influenced by meals. Bile acids secreted continuously in the intestinal lumen can irritate the intestinal mucosa producing local inflammation. At the same time, continuous exposure to bile acids is harmful, leading to chronic diarrhea and an increased risk of colonic tumors ${ }^{(42,50)}$. Therefore, prolonged exposure to bile acids, as well as inflammation, are among the possible mechanisms that create a connection between gallstones, cholecystectomy and digestive tract cancer. Studies have shown that the risk of cancer is higher in areas of the digestive tract closer to the common bile duct ${ }^{(6,51)}$.

The microbiota plays a crucial role in human physiology and metabolism. Although it is involved in many enzymatic, metabolic and structural roles, its responsibilities include: metabolizing certain nutrients and micronutrients, influencing the differentiation of intestinal epithelial cells, modulating the human immune system and preventing colonization of the body by pathogenic bacteria ${ }^{52,53)}$. It contains several enzymes that are able to provide critical changes to bile acids.

Based on these enzymatic roles, it is believed that the altered intestinal microbiota may be a cause and effect of the changed bile acids 
profile and the gallstones formation. Moreover, the association between gallstones, cholecystectomy and CRC may be related to the alterations of the intestinal microbiota $^{(0,36)}$. So far, cholecystectomy has been shown to alter the bacterial composition of the colon with significant growth of Bacteroidetes filant species, which have also been associated with colorectal cancer ${ }^{42,54)}$. There seems to be also a substantial reduction in bacterial diversity in gallstones patients ${ }^{(5)}$.

Of course, changes of gut microbiota and the mechanisms involved may be numerous in terms of biliary pathology, so these links require more detailed studies. However, it is very likely that an imbalance in the gut microbiota - liver axis can lead to gallbladder disease and carcinogenesis of colorectal cancer $^{36)}$.

Although there are many hypotheses that may explain the development of CRC in relation to gallstones and even with cholecystectomy, it is not clear yet whether the biliary pathology represents a specific risk factor for this type of neoplasia.

\section{Conclusions}

The incidence of CRC and the mortality rate are still high, so a thorough understanding of the molecular and cellular mechanisms underlying CRC is becoming increasingly important. The influence of bile acids on the development of colorectal tumors has been well outlined and significant progress has been made in elucidating the mechanisms by which they promote carcinogenesis. The whole process seems to be determined by the proportion between secondary and primary bile acids.

This ratio of concentrations is dependent on diet, intestinal flora and probably on biliary pathology. Focusing on the role of bile acids in the development of CRC would have an important significance, because changing the factors that increase the level of secondary bile acids could also change the incidence of CRC. Moreover, secondary bile acids found in feces can become a screening marker. Regarding biliary pathology, although gallstones share a lot of risk factors with $\mathrm{CRC}$, there is the possibility of expanding the effects they have on the digestive tract leading to the development of tumors. Research to date suggests that gallstones may reflect CRC-relevant pathways, such as bile acid metabolism, sex hormones, and cholesterol. Therefore, gallstones and cholecystectomy may be related to digestive system cancer through inflammation, altered bile flow, and changes in metabolic hormone levels. Moreover, it is emphasized that increased levels of secondary bile acids after gallstone disease and cholecystectomy are able to increase the risk of CRC.

Given that cholecystectomy is currently performed in most cases laparoscopically, preoperative exploration of the digestive tract by colonoscopy in high-risk patients could be an effective screening method and could then guide surgical behavior. The profile of patients at risk could include a detailed assessment of their health, including personal and family history, routine blood tests, as well as anthropometric measurements and lifestyle questionnaires. This would allow exploration of a wide range of potential causes of gallstones that are also compatible with CRC.

In any case, gallstones can represent a future risk of CRC and an underlying mechanism that needs to be further identified. Although the link between gallbladder pathology and colo-rectal neoplasia is uncertain, it requires a better understanding and broader studies. 


\section{References}

1. Mármol I, Sánchez-de-Diego C, Dieste AP, Cerrada E, Yoldi MJR. Colorectal carcinoma: A general overview and future perspectives in colorectal cancer. Int J Mol Sci. 2017. doi:10.3390/ijms18010197

2. Simon K. Colorectal cancer development and advances in screening. Clin Interv Aging. 2016. doi:10.2147/CIA.S109285

3. Arnold M, Sierra MS, Laversanne M, Soerjomataram I, Jemal A, Bray F. Global patterns and trends in colorectal cancer incidence and mortality. Gut. 2017. doi:10.1136/gutjnl-2015-310912

4. American Cancer Society. Cancer Facts \& Figures 2016. Cancer Facts Fig 2016. 2016. doi:10.1097/01. NNR.0000289503.22414.79

5. Ward HA, Murphy N, Weiderpass E, et al. Gallstones and incident colorectal cancer in a large pan-European cohort study. Int J Cancer. 2019. doi:10.1002/ijc.32090

6. Nogueira L, Freedman ND, Engels EA, Warren JL, Castro F, Koshiol J. Gallstones, cholecystectomy, and risk of digestive system cancers. Am J Epidemiol. 2014. doi:10.1093/aje/kwt322

7. Chiong C, Cox MR, Eslick GD. Gallstone disease is associated with rectal cancer: A meta-analysis. Scand J Gastroenterol. 2012. doi:10.3109/00365521. 2012. 660538

8. Chen Y, Wang Z. Cholelithiasis and cholecystectomy for colorectal cancer: a retrospective analysis. Zhonghua Wai Ke Za Zhi. 1998.

9. Rezasoltani S, Sadeghi A, Radinnia E, et al. The association between gut microbiota, cholesterol gallstones, and colorectal cancer. Gastroenterol Hepatol from Bed to Bench. 2019. doi:10.22037/ghfbb. v12i0.1823

10. Coccolini $F$, Catena $F$, Pisano $M$, et al. Open versus laparoscopic cholecystectomy in acute cholecystitis. Systematic review and meta-analysis. Int J Surg. 2015. doi:10.1016/j.ijsu.2015.04.083

11. CookJW, Kennaway EL, Kennaway NM. Production of tumours in mice by deoxycholic acid [10]. Nature. 1940. doi:10.1038/145627a0

12. Russell DW. The Enzymes, Regulation, and Genetics of Bile Acid Synthesis. Annu Rev Biochem. 2003. doi:10.1146/annurev.biochem.72.121801.161712

13. Fiorucci S, Cipriani S, Mencarelli A, Renga B, Distrutti

E, Baldelli F. Counter-Regulatory Role of Bile Acid Activated Receptors in Immunity and Inflammation. Curr Mol Med. 2012. doi:10.2174/156652410792231312

14. Redinger $R N$. The coming of age of our understanding of the enterohepatic circulation of bile salts. Am J Surg. 2003. doi:10.1016/S00029610(02)01212-6

15. Ridlon JM, Kang $D J$, Hylemon PB. Bile salt biotransformations by human intestinal bacteria. J Lipid Res. 2006. doi:10.1194/jIr.R500013-JLR200

16. Nagengast FM, Grubben MJAL, van Munster IP. Role of bile acids in colorectal carcinogenesis. Eur J Cancer. 1995. doi:10.1016/0959-8049(95)00216-6

17. Hill MJ. Bile flow and colon cancer. Mutat Res Genet Toxicol. 1990. doi:10.1016/0165-1110(90)90023-5

18. Magalhães $B$, Peleteiro $B$, Lunet $N$. Dietary patterns and colorectal cancer: Systematic review and metaanalysis. Eur J Cancer Prev. 2012. doi:10.1097/ CEJ.0b013e3283472241

19. Louis P, Hold GL, Flint HJ. The gut microbiota, bacterial metabolites and colorectal cancer. Nat Rev Microbiol. 2014. doi:10.1038/nrmicro3344

20. Hofmann AF, Cravetto $C$, Molino G, Belforte G, Bona $B$. Simulation of the metabolism and enterohepatic circulation of endogenous deoxycholic acid in humans using a physiologic pharmacokinetic model for bile acid metabolism. Gastroenterology. 1987. doi:10.1016/00165085(87)90430-6

21. Wilpart M. Co-mutagenicity of bile acids: Structureactivity relations. Eur J Cancer Prev. 1991. doi:10.1097/00008469-199110002-00008

22. Hylemon PB, Zhou H, Pandak WM, Ren S, Gil G, Dent $P$. Bile acids as regulatory molecules. J Lipid Res. 2009;50(8):1509-1520. doi:10.1194/jlr.R900007-JLR200 23. Chen $X$, Resh MD. Cholesterol depletion from the plasma membrane triggers ligand-independent activation of the epidermal growth factor receptor. J Biol Chem. 2002. doi:10.1074/jbc.M208327200

24. Payne C. Hydrophobic bile acids, genomic instability, Darwinian selection, and colon carcinogenesis. Clin Exp Gastroenterol. 2008. doi:10.2147/ceg.s4343 
25. Hylemon PB, Zhou H, Pandak WM, Ren S, Gil G, Dent P. Bile acids as regulatory molecules. J Lipid Res. 2009. doi:10.1194/Jlr.R900007-JLR200

26. Morotomi M, Guillem JG, LoGerfo P, Weinstein IB. Production of Diacylglycerol, an Activator of Protein Kinase C, by Human Intestinal Microflora. Cancer Res. 1990. J Lipid Res. 1997.

28. Bernstein H, Bernstein C, Payne CM, Dvorakova K, Garewal H. Bile acids as carcinogens in human gastrointestinal cancers. Mutat Res - Rev Mutat Res. 2005. doi:10.1016/j.mrrev.2004.08.001

29. Armaghany T, Wilson JD, Chu Q, Mills G. Genetic alterations in colorectal cancer. Gastrointest Cancer Res. 2012. 30. Portincasa P, Moschetta A, Palasciano G. Cholesterol gallstone disease. Lancet. 2006. doi:10.1016/S01406736(06)69044-2

31. Stinton LM, Shaffer EA. Epidemiology of gallbladder disease: Cholelithiasis and cancer. Gut Liver. 2012. doi:10.5009/gnl.2012.6.2.172

32. Sherlock S, Dooley J (James S. Diseases of the Liver and Biliary System. Blackwell Science; 2002.

33. Wang DQH, Afdhal NH. Genetic analysis of cholesterol gallstone formation: Searching for Lith (gallstone) genes. Curr Gastroenterol Rep. 2004. doi:10.1007/s11894-004-0042-1

34. Saklayen MG. The Global Epidemic of the Metabolic Syndrome. Curr Hypertens Rep. 2018. doi:10.1007/ s11906-018-0812-z

35. Njeze GE. Gallstones. Niger J Surg Off Publ Niger Surg Res Soc. 2013;19(2):49. doi:10.4103/11176806.119236

36. Søreide K. Gallstone Disease and Cancer Risk: Finding the Bug in the System. Gastroenterology. 2017. doi:10.1053/j.gastro.2017.04.028

37. Das KM, Vecchi M, Sakamaki S. A shared and unique epitope(s) on human colon, skin, and biliary epithelium detected by a monoclonal antibody. Gastroenterology. 1990. doi:10.1016/0016-5085(90)90839-S

38. Chiong C, Cox MR, Eslick GD. Gallstones are associated with colonic adenoma: A meta-analysis. World J Surg. 2012. doi:10.1007/s00268-012-1646-5

39. Shabanzadeh DM, Sørensen LT, Jørgensen $T$. Association Between Screen-Detected Gallstone Disease and Cancer in a Cohort Study. Gastroenterology. 2017. doi:10.1053/j.gastro.2017.02.013

40. Mamianetti A, Garrido D, Carducci CN, Vescina MC. Fecal bile acid excretion profile in gallstone patients. Medicina (B Aires). 1999.

41. Herrera J, Amigo L, Husche C, et al. Fecal bile acid excretion and messenger RNA expression levels of ileal transporters in high risk gallstone patients. Lipids Health Dis. 2009. doi:10.1186/1476-511X-8-53

42. Keren $N$, Konikoff FM, Paitan $Y$, et al. Interactions between the intestinal microbiota and bile acids in gallstones patients. Environ Microbiol Rep. 2015. doi:10.1111/1758-2229.12319

43. Borzellino G, Cordiano C. Biliary Lithiasis: Basic Science, Current Diagnosis and Management.; 2008. doi:10.1007/978-88-470-0763-5

44. Shukla VK, Tiwari SC, Roy SK. Biliary bile acids in cholelithiasis and carcinoma of the gall bladder. Eur J Cancer Prev. 1993. doi:10.1097/00008469-19930300000008

45. Caddy GR, Tham TCK. Symptoms, diagnosis and endoscopic management of common bile duct stones. Best Pract Res Clin Gastroenterol. 2006. doi:10.1016/j.bpg.2006.03.002

46. Grivennikov SI, Greten FR, Karin M. Immunity, Inflammation, and Cancer. Cell. 2010. doi:10.1016/j.cell.2010.01.025

47. Gibney EJ. Asymptomatic gallstones. BrJ Surg. 1990. doi:10.1002/bjs.1800770405

48. Tait N, Little JM. Fortnightly Review: The treatment of gall stones. BMJ. 1995;311(6997):99. doi:10.1136/ bmj.311.6997.99

49. Di Ciaula A, Wang $D Q H$, Wang $H H$, Bonfrate $L$, Portincasa P. Targets for current pharmacologic therapy in cholesterol gallstone disease. Gastroenterol Clin North Am. 2010. doi:10.1016/j.gtc.2010.02.005

50. Barrasa JI, Olmo N, Lizarbe MA, Turnay J. Bile acids in the colon, from healthy to cytotoxic molecules. Toxicol Vitr. 2013. doi:10.1016/j.tiv.2012.12.020

51. Tavani A, Rosato V, Di Palma F, et al. History of cholelithiasis and cancer risk in a network of case-control studies. Ann Oncol. 2012. doi:10.1093/annonc/mdr581

52. Clemente JC, Ursell LK, Parfrey LW, Knight R. The Impact of the Gut Microbiota on Human Health: An Integrative View - 1-s2.0-S0092867412001043main.pdf. Cell. 2012. doi:10.1016/j.cell.2012.01.035

53. Wu H, Tremaroli V, Bäckhed F. Linking Microbiota to Human Diseases: A Systems Biology Perspective. Trends Endocrinol Metab. 2015. doi:10.1016/j.tem.2015.09.011 54. Sobhani I, Tap J, Roudot-Thoraval F, et al. Microbial dysbiosis in colorectal cancer (CRC) patients. PLoS One. 2011. doi:10.1371/journal.pone.0016393

55. David LA, Maurice CF, Carmody RN, et al. Diet rapidly and reproducibly alters the human gut microbiome. Nature. 2014. doi:10.1038/nature12820 